\title{
Pengembangan Media Pembelajaran Berbasis Blended Learning pada Mata Kuliah Sejarah Indonesia Kontemporer Program Studi Pendidikan Sejarah Universitas Batanghari Jambi
}

\author{
Nur Agustiningsih ${ }^{1}$, Nurul Fitri ${ }^{2}$ \\ ${ }^{1}$ Dosen Universitas Batanghari Jambi, Indonesia \\ ${ }^{2}$ Dosen Universitas Batanghari Jambi, Indonesia \\ Correspondance email: nur.agustiningsih@unbari.ac.id
}

\begin{abstract}
Abstrak: Tujuan dari penelitian ini adalah untuk mengetahui (1) proses pengembangan media pembelajaran berbasis blended learning pada mata kuliah sejarah Indonesia Kontemporer Program Studi Pendidikan Sejarah Universitas Batanghari Jambi (2) kelayakan media pembelajaran berbasis blended learning pada mata kuliah sejarah Indonesia Kontemporer Program Studi Pendidikan Sejarah Universitas Batanghari Jambi. Jenis penelitian ini adalah pengembangan. Penelitian ini menekankan upaya untuk menghasilkan produk tertentu yang akan digunakan dalam bidang ilmu tertentu dan juga dapat digunakan dalam kegiatan yang membutuhkannya. Pengembangan yang dilakukan dalam penelitian ini adalah pengembangan media pembelajaran berbasis blended learning berupa ebook. Untuk menentukan kelayakan media, para ahli media dan ahli materi memvalidasi media yang telah dibuat dan kemudian melakukan uji coba media kepada siswa, uji coba dilakukan pada tiga tahap, one to one, small group, dan field test. Hasil penelitian menunjukkan bahwa (1) tahap pengembangan media berbasis blended learning pada mata kuliah Sejarah Indonesia Kontemporer mengadopsi langkah-langkah atau tahapan yang dikembangkan oleh ADDIE yang terdiri dari lima tahap, yaitu: analisis, desain, pengembangan, implementasi, dan evaluasi. (2) Hasil penilaian oleh ahli media untuk semua aspek diperoleh skor rata-rata 4,25 dengan kategori sangat baik dan layak untuk digunakan. Selanjutnya berdasarkan penilaian ahli media, rata-rata semua aspek adalah 4,35 dan 4,48 setelah direvisi dengan kategori sangat baik sehingga materi layak untuk digunakan. Kelayakan media pembelajaran berbasis blended learning mata kuliah sejarah Indonesia Kontemporer berdasarkan penilaian mahasiswa dalam field test diperoleh rata-rata semua aspek 4,45 dalam kategori sangat baik sehingga media sangat layak untuk digunakan dalam kegiatan pembelajaran.
\end{abstract}

Kata Kunci: Media pembelajaran, blended learning

Abstract: The purpose of this research is to find out (1) the process of learning media development based blended learning for Indonesia Contemporary History subject of History Education Program batanghari University Jambi, (2) The eligibility of learning media based blended learning for Indonesia Contemporary History subject of History Education Program Batanghari University Jambi. The types of this research are research and development. This research emphasizes an effort to produce certain products that will be used in certain fields of science and can also be used in an activity that needs it. The development which was carried out in this research is developing of learning media based on blended learning in the form of an ebook. To determine the feasibility of the media, the media experts and material experts validated the media that had been made and then conducted a media trial to the students, the trial was carried out on three stages, one to one, small group trials, and field test trials. The results showed that (1) the stages of developing blended learning based media in Indonesia Contemporary History subject adopted the steps or stages which were developed by ADDIE which consisted of five stages, they are: analysis, design, development, implementation, and evaluation. (2) The results of the assessment by media experts for all aspects obtained an average score of 4.25 with very good category and reasonable to be used. Furthermore, based on the media expert's assessment, the average of all aspects is 4.35 dan 4,48 after revision with a very good category so that the material reasonable to be used. The advisability of blended learning based media in Indonesia Contemporary based on student assessment in the field test obtained an average of all aspects 4.45 in the very good category so that the media was very suitable to be used in this learning activity.

Keyword: Learning Media, Blended Learning

\section{PENDAHULUAN}

Salah satu kegunaan mempelajari sejarah adalah untuk mengetahui masa lalu. Mempelajari sejarah bukan hanya sekedar melihat ke belakang melihat kembali peristiwa yang telah berlalu namun juga untuk melihat masa depan. Dengan mempelajari sejarah kita dapat mengetahui akar budaya dan perjuangan para pendahulu kita dalam membentuk bangsa ini. Mempelajari sejarah diperlukan untuk membangun jati diri dan kesadaran nasionalisme sebagai bangsa indonesia, Sehingga kesadaran sejarah perlu ditumbuhkan terutama pada generasi muda. Meskipun 
demikian minat untuk mempelajari sejarah masih kurang. Hal ini bisa disebabkan oleh banyak faktor salah satunya adalah pengemasan dan penyampain materi sejarah dikelas kurang menarik dan bahkan dapat dikatakan membosankan bagi generasi saat ini.

Era yang dilalui generasi sekarang ini tentu berbeda dengan masa-masa sebelumnya, sehingga pembelajaran sejarah harus didesain secara menarik sesuai dengan warna jamannya. Saat ini Indonesia telah memasuki era revolusi 4.0 yang ditandai dengan perkembangan teknologi yang begitu cepat terutama teknologi komunikasi dan masivnya penggunaan jaringan internet. Hal ini tentu saja juga berpengaruh terhadap dunia pendidikan dan pola komunikasi dalam pembelajaran antara pendidik dan peserta didik. Pembelajaran berbasis teknologi informasi dan komunikasi menjadi sesuatu yang penting untuk dikembangkan dalam pembelajaran sejarah saat ini. Salah satu upaya yang dapat dilakukan untuk meningkatkan ketertarikan dalam pembelajaran sejarah adalah dengan mengembangkan media-media pembelajaran yang mengintergrasikan teknologi. Media pembelajaran dapat menjadi salah satu alat bantu untuk menyampaikan materi ataupun pesan sehingga mudah dipahami oleh peserta didik dan lebih menarik perhatian serta minat terhadap sejarah.

Menurut Basri dan Sumargono (2018:4) media pembelajaran adalah segala sesuatu yang digunakan atau disediakan oleh guru dimana penggunaannya diintergrasikan ke dalan tujuan dan isi pembelajaran sehingga dapat membantu meningkatkan kualitas kegiatan pembelajaran serta mencapai kompetensi pembelajarannya. Hal ini sesuai dengan beberapa penelitian terdahulu menyatakan bahwa penggunaan media efektif dalam pembelajaran sejarah dan dapat meningkatkan hasil belajar (Reka Seprina, 2013 dan Auroran Nandia Febranti, 2015).

Pembelajaran saat ini mulai bergeser menjadi pembelajaran berbasis digital. Salah satu rancangan pembelajaran yang mengintegrasikan teknologi informasi dan komunikasi adalah melalui pembelajaran blended learning, dalam pembelajaran blended learning diperlukan juga rancangan-rancangan media pembelajaran yang dapat mendukung pembelajaran tersebut. Media-media yang akan dikembangkan dalam pembelajaran sejarah khususnya dalam penelitian ini yaitu mata kuliah Sejarah Indonesia Kontemporer adalah buku elektronik berbasis android, dan video berbasis powerpoint. sedangkan untuk pembelajaran online dilakukan dengan menggunakan edmodo.

Berdasarkan latar belakang tersebut, maka rumusan masalah dalam penelitian ini adalah sebagai berikut (1) Bagaimana Pengembangan media pembelajaran berbasis blended learning pada mata kuliah sejarah indonesia kontemporer?, (2) Bagaimana Kelayakan media pembelajaran berbasis blended learning pada mata kuliah sejarah Indonesia kontemporer?

\section{METODE PENELITIAN}

Metode yang digunakan dalam penelitian ini adalah penelitian R\&D yang merupakan penelitian pengembangan. Penelitian pengembangan adalah rangkaian proses atau tahapan-tahapan yang dilakukan dalam mengembangkan produk baru atau menyempurnakan, dan memanfaatkan produk yang sudah ada. Borg and Gall (1983) penelitian pengembangan adalah proses yang digunakan untuk mengembangkan dan memvalidasi produk.

Prosedur penelitian yang peneliti gunakan mengadaptasi model pengembangan ADDIE. Gafur (2012: 38) mengemukakan bahwa model ADDIE terdiri dari 5 (lima) komponen atau langkah, yaitu: Analisis (Analysis), Desain (Design), Pengembangan (Develop), Implementasi (Implement), Evaluasi (Evaluate)

Dalam penelitian ini instrument yang digunakan meliputi: lembar observasi, kuesioner (lembar validasi), serta pedoman wawancara. Lembar observasi dan wawancara digunakan untuk mencari informasi-informasi dari lapangan dan penelitian pendahuluan. Kuesioner (lembar validasi) digunakan untuk mengukur kelayakan produk yang telah dikembangkan.

Teknik analisis data dalam penelitian ini yaitu: (1) Teknik analisis data kualitatif, Data kualitatif dalam penelitian ini diperoleh dari hasil observasi dan wawancara. Analisis data dilakukan dengan mengorganisasikan data, menjabarkan kedalam unit-unit, melakukan sintesa, menyusun ke dalam pola, memilih mana yang penting dan yang akan dipelajari, dan membuat kesimpulan yang dapat diceritakan kepada orang lain (Sugiyono, 2010: 333). Data penelitian yang diperoleh selama proses penelitian dicatat kemudian dijabarkan secara deskriptif dan ditarik kesimpulan. (2) Teknik analisis data kuantitatif, Analisis kuantitaif dilakukan untuk mengolah data berupa skor penilaian ahli materi, ahli media, dan mahasiswa. Data kuantitatif dikonversi menjadi data kualitatif menggunakan teknik pengkriteriaan dengan skala 5. Konversi data kuantitatf menjadi kualitatif dilakukan dengan membandingkan skor rata-rata angket. Skor rata-rata angket dihitung dengan rumus:

$$
\bar{x}=\frac{\sum x}{N}
$$

Keterangan:

$\bar{x}=$ Skor rata rata

$\Sigma \mathrm{x}=$ Jumlah skor 
$\mathrm{N} \quad=$ Jumlah penilai

Untuk mengubah data kuantitatif menjadi kualitatif dengan kriteria yang mengacu pada rumus konversi Widoyoko (2009: 238) sebagai berikut.

\section{Tabel 1}

\section{Pedoman Konversi Data Kuantitatif ke Data Kualitatif}

\begin{tabular}{llll}
\hline Skala & \multicolumn{1}{c}{ Rumus } & \multicolumn{1}{c}{ Rerata Skor } & \multicolumn{1}{c}{ Klasifikasi } \\
\hline 5 & $\mathrm{X}>\overline{\mathrm{X}} \mathrm{i}+1,8 \times \mathrm{sbi}$ & $>4,2$ & Sangat Baik \\
\hline 4 & $\overline{\mathrm{X}} \mathrm{i}+0,6 \times \mathrm{sbi}<\mathrm{X} \leq \overline{\mathrm{X}} \mathrm{i}+1,8 \times \mathrm{sbi}$ & $>3,4-4,2$ & Baik \\
\hline 3 & $\overline{\mathrm{X}} \mathrm{i}-0,6 \times \mathrm{sbi}<\mathrm{X} \leq \overline{\mathrm{X}} \mathrm{i}+0,6 \times \mathrm{sbi}$ & $>2,6-3,4$ & Cukup \\
\hline 2 & $\overline{\mathrm{X}} \mathrm{i}-1,8 \times \mathrm{sbi}<\mathrm{X} \leq \overline{\mathrm{X}} \mathrm{i}-0,6 \times \mathrm{sbi}$ & $>1,8-2,6$ & Kurang \\
\hline 1 & $\mathrm{X} \leq \overline{\mathrm{X}} \mathrm{i}-1,8 \times \mathrm{sbi}$ & $\leq 1,8$ & Sangat Kurang \\
\hline
\end{tabular}

\section{HASIL DAN PEMBAHASAN}

Perkembangan teknologi informasi dan komunikasi telah membawa perubahan besar dalam berbagai bidang kehidupan termasuk dalam bidang pendidikan. Dengan kemajuan teknologi tersebut belajar tidak hanya dilakukan secara tatap muka di dalam kelas namun juga dilakukan pembelajaran secara online. penggabungan dari pembelajaran tatap muka dan online tersebut kita kenal dengan istilah blended learning. Menurut Bersin (2004) mendefiniskan blended learning sebagai: "The combination of different training "media" (technologies, activities, and types of events) to create an optimum training program for a specific audience. The term "belnded" means that traditional instructorled training is being supplementedwith o ther electronic formats. In the context of this book, blended learning programs use many different forms of e-learning, perhaps complemented with instructor-led training and other live formats". Pengembangan media pembelajaran diperlukan untuk menunjang pembelajaran blended learning tersebut. Menurut Daryanto (2011: 5) Penggunaan media dalam proses pembelajaran memiliki manfaat seperti memperjelas pesan agar tidak terlalu verbalitas, mengatasi keterbatasan ruang, waktu, tenaga, dan daya indra, menimbulkan gairah, memungkinkan peserta didik belajar secara mandiri, memberi rangsangan, dapat menyalurkan pesan, serta dapat mengkomunikasikan lima komponen pembelajaran yaitu guru, bahan pembelajaran, media pembelajaran, peserta didik, dan tujuan pembelajaran.

Di dalam blended learning diperlukan media-media pendukung, salah satunya adalah media elektronik. Penelitian ini bertujuan untuk menghasilkan produk media pembelajaran berbentuk $e$-book berbasis android dimana di dalamnya terdapat video berbasis ppt dan soal yang bisa dikerjakan secara online. Langkah-langkah pengembangannya mendadopsi model pengembangan ADDIE yang meliputi analisys (Analisis), design (desain), development (Pengembangan) dan evaluation (evaluasi).

\section{Analisis (Analysis)}

Pada tahap ini peneliti menggunakan teknik observasi dan wawancara yang dilakukan terhadap mahasiswa dan dosen pengampu mata kuliah sejarah indonesia kontemporer. Pada kegiatan Ini dilakukan untuk mendapatka informasi mengenai proses pembelajaran, karakteristik siswa, media pembelajaran yang tersedia, metode yang sering digunakan oleh dosen dan sumber belajar yang digunakan oleh dosen. Dari kegiatan ini diperoleh beberapa data yaitu media yang digunakan oleh dosen berupa powerpoint, metode pebelajaran yang sering digunakan adalah metode diskusi, dosen menggunakan bahan ajar berupa buku teks dan artikel ilmiah, dosen mengalami kendala dalam mencari referensi terutama yang berkaitan dengan materi sejarah kontroversi, mahasiswa memiliki handphone android, mahasiswa telah memiliki akun edmodo sebagai sarana untuk belajar online

Berdasarkan analisis materi yang akan dipilih untuk pengembangan media adalah peristiwa gerakan 30 September 1965. Materi ini dipilih karena merupakan materi yang termasuk dalam materi sejarah kontroversi yang ada dalam periode kontemporer, dimana untuk memahami sejarah kontoversi mahasis wa membutuhkan banyak sumber belajar yang harus di akses, salah satunya adalah melalui media pembelajaran.

Dari data yang diperoleh dari hasil observasi dan wawancara tersebut penelitia akan mengembangkan media pembelajaran dalam bentuk elektronik book atau buku digital dimana didalamnya terdapat konten text, video yang dapat diputar di android dan soal yang bisa dikerjakan secara online, dapat membantu dosen dalam pembelajaran dan meningkatkan minat dan kemadirian belajar mahasiswa.

\section{Desain (Design)}

Tahap kedua ini adalah perancangan media pembelajaran, dalam tahap ini terbagi menjadi 2 tahap yaitu (1) Perancangan desain Produk. Peneliti mulai membuat konsep buku digital yang akan disesuaikan dengan materi dan tujuan pembelajaran yang akan digunakan. Adapun rancangan buku digital yang akan dibuat terdiri dari beberapa 
bagian yaitu COVER (Judul Nama Mata Kuliah, Topik/Materi Pembelajaran Penulis, Daftar Isi. PENDAHULUAN (Deskripsi singkat materi, rasionalisasi, dan relevansi, Peta Konsep. PEMBELAJARAN (Tujuan Pembelajaran, Uraian Materi, Rangkuman, Latihan) DAFTAR PUSTAKA (2) Penyusunan Instrumen Penilaian. Instrumen penilaian yang peneliti susun terdiri atas 3 (tiga), yaitu instrumen penilaian tentang kelayakan materi oleh ahli materi, instrumen penilaian tentang kelayakan media oleh ahli media, dan instrumen penilaian tentang kelayakan materi dan media oleh mahasiswa. Instrumen-instrumen penilaian tersebut peneliti susun dalam bentuk angket dengan 5 (lima) alternatif jawaban, yaitu Sangat Baik, Baik, Cukup, Tidak Baik, dan Sangat Tidak Baik.

\section{Pengembangan (Develop)}

\section{Pembuatan Media Pembelajaran}

pada tahap pengembangan produk meliputi kegiatan seperti menyiapkan software, menyiapkan bahan, perancangan desain, serta penggabungan teks, video, dan gambar dalam satu aplikasi. Konten media pembelajaran yang berupa EBook ini terdiri dari teks, video, gambar dan soal online. (1) Teks, Materi yang akan Untuk pembuatan materi dalam bentuk teks menggunakan aplikasi Ms. Word 2007 disimpan dalam bentuk file HTML. (2) Video, Untuk pembuatan video menggunakan aplikasi powerpoint 2010. Video yang dibuat melalui powerpoint akan tersimpan dalam bentuk file Widows Media Video (WMV). Selanjutnya video tersebut harus di convert dalam betuk file MP4 dengan aplikasi video converter agar dapat terbaca pada aplikasi. (3) Gambar, Beberapa halaman pada ebook yang dikembangkan dibuat dalam bentuk gambar supaya lebih menarik, diantaranya adalah halaman cover, kata pengantar, kompetensi dasar, tujuan pembelajaran, pada sub-sub judul, rangkuman, halaman latihan soal dan sampul belakang. Gambar yang diimport dalam aplikasi semua harus dalam bentuk JPEG. Sebagian gambar di download dari internet kemudian di desain ulang digambungnkan dengan beberapa gambar lain maupun teks kemudian file di export dalam bentuk file JPEG. Untuk pembuatan gambar ini menggunakan aplikasi Corel Draw X4. (3) Soal online. Pada halaman latihan terdapat soal online. soal online tersebut dibuat dengan menggunakan aplikasi google form yang terdapat pada akun gmail. Untuk mengerjakan soal tersebut mahasiswa tinggal mengklik pada link yang sudah ditautkan pada halaman latihan. Untuk dapat mengisi soal latihan tersebut harus dalam keadaan internet aktif.

Konten materi berupa teks, video, gambar dan soal online tadi digabungkan menggunakan aplikasi sigil. file yang dihasilkan bebrbentuk EPUB. Untuk dapat membaca file EPUB harus menggunakan aplikasi tambahan yaitu (1) aplikasi desktop meenggunakan GHP Reader. (2) Android menggunakan ereader pretigio diinstall dari google play. (3) iOS menggunakan iBooks. (4) Google Chrome mengunakan Readium diinstall dari chrome store namun beberapa video tidak dapat diputar

\section{Validasi Media Pembelajaran}

Pada tahap ini dilakukan beberapa kegiatan yaitu validasi media oleh tim ahli yang terdiri dari ahli media dan ahli materi.

1. Validasi ahli materi

\section{a. Penilaian Ahli Materi}

Validasi ahli materi bertujuan untuk menguji kelengkapan materi, kebenaran materi dan sistematika materi. Hasil data validasi ahli materi dapat dilihat pada tabel dibawah ini

Tabel 2

\section{Data Hasil Penilaian Materi}

\begin{tabular}{|c|c|c|c|}
\hline No & Aspek & Rerata Skor & Kategori \\
\hline 1 & Materi & 4,40 & Sangat Baik \\
\hline 2 & Bahasa & 4,30 & Sangat Baik \\
\hline 3 & Pembelajaran & 4,36 & Sangat Baik \\
\hline \multicolumn{2}{|c|}{ Jumlah } & 4,35 & Sangat Baik \\
\hline
\end{tabular}

Dari tabel diatas diketahui bahwa hasil penilaian ahli materi untuk aspek materi diperoleh rerata skor 4.4 dengan kategori "Sangat Baik", aspek bahasa diperoleh rerata skor 4,30 dengan kategori "Sangat Baik", dan pada aspek pembelajaran diperoleh rerata skor 4,36 pada kategori "Sangat Baik". Total keseluruh dari aspek pada penilaian materi adalah 4,35 dengan kategori "Sangat Baik". Penilaian dari validator ini peneliti jadikan sebagai dasar dalam merevisi materi pembelajaran. Setelah peneliti melakukan revisi terhadap materi dilakukan validasi materi kembali. Adapun hasil penilaian ahli materi setelah revisi dapat dilihat pada tabel sebagai berikut: 
Tabel 3

Data Hasil Penilaian Materi setelah revisi

\begin{tabular}{|c|c|c|c|}
\hline No & Aspek & Rerata Skor & Kategori \\
\hline 1 & Materi & 4,50 & Sangat Baik \\
\hline 2 & Bahasa & 4,50 & Sangat Baik \\
\hline 3 & Pembelajaran & 4,45 & Sangat Baik \\
\hline Jum & & 4,48 & Sangat Baik \\
\hline
\end{tabular}

Dari tabel diatas diketahui bahwa hasil penilaian ahli materi untuk aspek materi diperoleh rerata skor 4,50 dengan kategori "Sangat Baik", aspek bahasa diperoleh rerata skor 4,50 dengan kategori "Sangat Baik", dan pada aspek pembelajaran diperoleh rerata skor 4,45 pada kategori "Sangat Baik". Total keseluruh dari aspek pada penilaian materi adalah 4,48 dengan kategori "Sangat Baik".

b. Revisi Materi

Adapun Saran atau komentar yang diberikan oleh ahli materi seperti pada tabel berikut ini.

Tabel 4

Data Saran/komentar Ahli Materi

\begin{tabular}{llll}
\hline No & \multicolumn{1}{c}{ Aspek } & & \multicolumn{1}{c}{ Saran Masukan } \\
\hline 1 & Materi & - & Tambahkan peta konsep \\
& & - & Tambahkan lagi berbagai pendapat tentang dalang terjadinya gerakan \\
& & 30 September \\
\hline 2 & Bahasa & - & $\begin{array}{l}\text { Penulisan perlu di perbaiki terutama tanda baca dan pola struktur } \\
\text { kalimatnya }\end{array}$
\end{tabular}

2. Validasi Media

a. Penilaian Ahli Media

Berdasarkan penilaian ahli media data hasil penilaian tersebut dapat dilihat pada tabel dibawah ini.

Tabel 5

Data Hasil Penilaian Ahli Media

\begin{tabular}{llcc}
\hline No & \multicolumn{1}{c}{ Aspek } & $\begin{array}{c}\text { Rerata } \\
\text { Skor }\end{array}$ & Kategori \\
\hline 1 & Tampilan dan Penyajian & 4,40 & Sanga Baik \\
\hline 2 & Pemrograman & 4,1 & Baik \\
\hline Jumlah & 4,25 & Sangat Baik \\
\hline
\end{tabular}

Dari tabel diatas diketahui hasil penilaian oleh ahli media untuk aspek tampilan dan penyajian diperoleh rerata skor 4,40 tergolong kategori, sangat baik aspek pemrograman diperoleh rerata skor dengan kategori 4,10 dengan kategori baik, Total keseluruh dari aspek pada penilaian media adalah 4,25 dengan kategori "sangat baik"

b. Revisi Media

Validator ahli media memberikan beberapa saran/masukan yang bermanfaat sebagai acuan untuk memperbaiki e-book agar lebih baik. Saran/masukan yang diberikan dapat dilihat pada tabel berikut ini:

Tabel 6

Saran Perbaikan Validasi Ahli Media

\begin{tabular}{|c|c|c|}
\hline No & Aspek & Saran Masukan \\
\hline 1 & Tampilan dan Penyajian & $\begin{array}{ll}\text { - } & \text { Desain cover di tambah variasi warnanya } \\
\text { - } & \text { Tambahkan gambar animasi supaya lebih } \\
\text { menarik } & \\
\text { - } & \text { Tambahkan lagi video dokumenter tentang } \\
\text { peristiwa-peristiwa seputar gerakan } 30 \\
\text { September }\end{array}$ \\
\hline
\end{tabular}




\section{Implementasi (Implement)}

Tahap ini merupakan uji coba dari produk awal media video pembelajaran yang dihasilkan. Uji coba produk dilaksanakan dalam tiga tahapan yaitu uji coba perorangan/one to one, uji coba kelompok kecil/small group dan uji coba lapangan/field test. Berikut ini uji coba yang dilakukan pada tahap implementasi:

\section{Uji Coba perorangan / one to one}

Uji coba kelompok kecil dilakukan pada 3 orang mahasiswa pendidikan sejarah FKIP Unbari. Uji coba ini menghasilkan data respon penilaian mahasiswa terhadap produk serta komentar/saran produk yang akan dijadikan acuan perbaikan sebelum Uji coba kelompok kecil. Data respon penilaian mahasiswa selanjutnya dianalisis untuk mengetahui hasil respon penilaian produk menurut mahasiswa pada uji coba kelompok perorangan. Adapun hasil penilaian dari uji coba perorangan dapat dilihat pada tabel dibawah ini.

\section{Tabel 7}

Data Rerata Skor dan Kategori dari Uji Coba perorangan / one to one

\begin{tabular}{llll}
\hline No & \multicolumn{1}{c}{ Aspek } & $\begin{array}{c}\text { Rerata } \\
\text { Skor }\end{array}$ & \multicolumn{1}{c}{ Kategori } \\
\hline 1 & Materi & 3,67 & Baik \\
\hline 2 & Pembelajaran & 4,33 & Sangat Baik \\
\hline 3 & Tampilan dan penyajian & 4,08 & Baik \\
\hline 4 & Pemrograman & 4,44 & Sangat Baik \\
\hline Rerata Skor & 4,13 & Baik \\
\hline
\end{tabular}

Dari tabel diatas diketahui bahwa hasil materi pembelajaran diperoleh rerata skor 3,67 (dengan kategori "Baik"), aspek pembelajaran diperoleh rerata.4,33 (dengan kategori "sangat Baik"), Aspek tampilan dan penyajian diperoleh rerata skor 4.08 (dengan kategori "Baik"), aspek pemrograman diperoleh rerata skor 4,44 (dengan kategori "Sangat Baik"), Rerata skor total seluruh aspek adalah 4.13 (dengan kategori "Baik"). Sehingga secara keseluruhan dapat dikatakan media yang dikembangkan berdasarkan respon penilaian mahasiswa pada uji coba one to one dalam kategori "Baik" sebagai media pembelajaran.

Ada beberapa saran dan komentar dari mahasiswa dalam uji coba one to noe ini yaitu media yang digunakan sudah baik, namun ada teks yang tidak timbul tapi ada suaranya, saran lebih diperhatikan penulisan karea ada teks atau kalimat yang kurang atau salah. Video sebaiknya ditambah.

\section{Uji Coba Kelompok Kecil / small group}

Uji coba kelompok kecil dilakukan pada 8 orang mahasiswa Prodi Pendidikan Sejarah FKIP Unbari. Uji coba ini menghasilkan data respon penilaian mahasiswa terhadap produk serta komentar/saran produk yang akan dijadikan acuan perbaikan sebelum Uji coba kelompok besar/lapangan. Data respon penilaian siswa selanjutnya dianalisis untuk mengetahui hasil respon penilaian produk menurut mahasiswa pada uji coba kelompok kecil. Adapun hasil penilaian dari uji coba kelompok kecil dapat dilihat pada tabel dibawah ini.

Tabel 8

\section{Data Rerata Skor dan Kategori dari Uji Coba Kelompok kecil / small group}

\begin{tabular}{llcl}
\hline No & \multicolumn{1}{c}{ Aspek } & $\begin{array}{c}\text { Rerata } \\
\text { Skor }\end{array}$ & Kategori \\
\hline 1 & Materi & 4,46 & Sangat Baik \\
\hline 2 & Pembelajaran & 4,25 & Sangat Baik \\
\hline 3 & Tampilan dan penyajian & 4,31 & Sangat Baik \\
\hline 4 & Pemrograman & 4,40 & Sangat Baik \\
\hline Rerata Skor & 4.35 & Sangat Baik \\
\hline
\end{tabular}

Dari tabel diatas diketahui bahwa hasil materi pembelajaran diperoleh rerata skor 4.46 (dengan kategori "sangat Baik"), aspek pembelajaran diperoleh rerata.4,25 (dengan kategori "sangat Baik"), Aspek tampilan dan penyajian diperoleh rerata skor 4.31 (dengan kategori "sangat Baik"), aspek pemrograman diperoleh rerata skor 4,40 (dengan kategori "sangat Baik"), Rerata skor total seluruh aspek adalah 4.35 (dengan kategori "Sangat Baik"). Sehingga secara keseluruhan dapat dikatakan bahwa e-book berdasarkan respon penilaian mahasiswa pada uji coba kelompok sedang kategori "Sangat Baik" sebagai media pembelajaran. 
Adapun komentar yang diberikan oleh mahasiswa dalam uji kelompok kecil/small group adalah sebagai berikut: sangat membantu dalam mencerna materi, media pembelajaran yang digunakan sangat menarik, sangat membantu dalam meningkatkan minat belajar

\section{Uji Coba lapangan /Field Test}

Uji coba lapangan / Filed test dilakukan pada mahasiswa prodi pendidikan sejarah FKIP Unbari berjumlah 17 orang mahasiswa. Uji coba ini menghasilkan data respon penilaian siswa terhadap produk yang dikembangkan. Data respon penilaian mahasiswa selanjutnya dianalisis untuk mengetahui hasil respon penilaian produk pada uji coba lapangan/ Field test.

Data respon penilaian mahasiswa selanjutnya dianalisis untuk mengetahui hasil respon penilaian produk pada uji coba lapangan/field test

Tabel 9

Data Rerata Skor dan Kategori dari Uji Coba lapangan

\begin{tabular}{clcl}
\hline No & \multicolumn{1}{c}{ Aspek } & $\begin{array}{c}\text { Rerata } \\
\text { Skor }\end{array}$ & Kategori \\
\hline 1 & Materi & 4,29 & Sangat Baik \\
\hline 2 & Pembelajaran & 4.50 & Sangat Baik \\
\hline 3 & Tampilan dan penyajian & 4,51 & Sangat Baik \\
\hline 4 & Pemrograman & 4,50 & Sangat Baik \\
\hline Rerata Skor & 4.45 & Sangat Baik \\
\hline
\end{tabular}

Dari tabel diatas diketahui bahwa hasil materi pembelajaran diperoleh rerata skor 4.29 (dengan kategori "sangat Baik"), aspek pembelajaran diperoleh rerata 4,50 (dengan kategori "sangat Baik"). Aspek tampilan dan penyajian diperoleh rerata skor 4.51 (dengan kategori "Sangat Baik"), aspek pemrograman diperoleh rerata skor 4,50 (dengan kategori "sangat Baik"). Rerata skor total seluruh aspek adalah 4.45 (dengan kategori "Sangat Baik"). Sehingga secara keseluruhan dapat dikatakan bahwa e-book berdasarkan respon penilaian pada uji coba lapangan kategori "Sangat Baik" sebagai media pembelajaran.

Adapun saran dan komentar yang diberikan mahasiswa pada uji coba lapangan adalah Media yang digunakan sangat menarik, membuat proses belajar mengajar berjalan dengan asik, medianya sangat menaik dan kreatif, tetapi kalau bisa suaranya di buat lebih santai, lebih mengoptimalkan sumber untuk melengkapi materi, media pembelajaran ini sangat memotivasi mahasiswa dan harus lebih dikembangkan lagi, media pembelajaran sangat bagus dan sangat membantu, media pembelajarannya sangat bagus dan lebih bagus lagi jika materinya diperbanyak, media ini sangat membantu mahasiswa yang malas membaca, sangat membantu belajar terutama untuk yang tidak suka membaca, medianya menarik dan mudah dipahami cocok untuk yang malas membaca. Dapat disimpulkan bahwa mahasiswa memberikan respon yang positif terhadap media yang dikembangkan.

Berdasarkan hasil respon mahasiswa tersebut bahwa untuk mengatasi hambatan-hambatan dalam pembelajaran sejarah indonesia kontemporer dapat dijembatani melalui pengembangan media pembelajaran yang inovatif dan mengintegrasikan teknologi didalamnya serta mengikut sertakan mahasiswa terlibat aktif dalam penggunaan media tersebut. Hal ini sesuai dengan fungsi media pembelajaran menurut Sudjana dan Rifa'i (2009:2) yaitu pembelajaran akan lebih menarik perhatian sehingga dapat menumbuhkan motivasi belajar, metode belajara akan lebih berfariasi tidak hanya semata-mata komunikasi verbal melalui katakata sehingga tidak merasa bosan, peserta didik lebih banyak melakukan kegiatan belajar. media pembelajaran sendiri akan memudahkan mahasiswa untuk memahami dan menangkap peristiwa-peristiwa sejarah.

\section{Evaluasi}

Evaluasi adalah suatu proses atau kegiatan sistematik, berkelanjutan dan menyeluruh (Zainal Arifin, 2019: 18). Pada tahap evaluasi dilakukan dari hasil uji coba produk media pembelajaran pada pengguna (mahasiswa). Berikut hasil dari tahap evaluasi:

a. Tahap validasi

Revisi dilakukan setelah media pembelajaran divalidasi oleh ahli materi dan ahli media berupa komentar dan saran yang diberikan sebagai bahan perbaikan produk media pembelajaran. Setelah produk diperbaiki sesuai dengan saran dan komentar dari ahli media dan materi maka media pembelajaran siap untuk diujicobakan pada mahasiswa.

b. Tahap Uji Coba 
Pada tahap ini uji coba dilakukan dalam tiga tahap yaitu tahap one to one, small group dan field test. evaluasi pada tahap ini dilakukan dengan menganalisis penilaian mahasiswa tetang materi dan media yang dikembangkan. Hasil penilaian yang berupa saran dan komentar digunakan sebagai data acuan untuk perbaikan produk

c. Produk akhir

Setelah dilakukan proses revisi melalui melalui proses validasi dan uji coba diperoleh produk akhir media pembelajaran berbasis blended learning berupa $e$-book berbasis android

\section{SIMPULAN}

1. Pengembangan media pembelajaran berbasis blended learning pada mata kuliah sejarah indonesia kontemporer mengadopsi model pengembangan ADIE yang terdiri dari lima tahapan yaitu tahap analisis, tahap desain, development, implementasi, dan terakhir evaluasi. Pada tahap evaluasi dilakukan peneliti pada tahap implementasi dan uji coba produk media pembelajaran.

2. Media pembelajaran layak untuk digunakan berdasarkan penilaian ahli materi dan media dengan dengan nilai rerata ahli materi 4,35 pada validasi tahap I dan 4,48 pada validasi tahap revisi dengan kategori "sangat baik", dan penilaian ahli media dengan nilai rerata 4,25 dengan kategori "sangat baik"

3. Pada saat uji coba media pembelajaran dilakukan sebanyak tiga kali. Pada uji coba pertama yaitu one to one (perorangan) berjumlah 3 orang yang memberi penilaian kategori "baik" dengan rerata nilai 4,13. Pada uji coba kedua yaitu small group (kelompok kecil) berjumlah 8 orang mahasiswa yang memberi penilaian "sangat baik" dengan perolehan nilai rerata 4.35. selanjutnya tahap uji coba terakhir yaitu field test (lapangan) yang berjumlah 17 orang mahasiswa yang memberi penilaian "sangat baik" dengan perolehan nilai rerata 4,45.

\section{DAFTAR PUSTAKA}

Aurora Nandia Febrianti. 2015. Pengembangan Media Pembelajaran Sejarah Berbasis Audio Visual Situs Purbakala Pugung Raharjo Untuk Meningkatkan Kesadaran Sejarah Siswa Kelas X SMA Negeri 1 Kota Gajah. Surakarta: UNS. Tesis. 2015

Basri, Sumargono. 2018. Media Pembelajaran Sejarah. Yogykarta: Graha Ilmu.

Bersin, Josh. 2004. The Blended Bearning Book:Best Bractices, Proven Methodologies, and Lessons Learned. San Francisco: Pfeiffer.

Daryanto. 2011. Media Pembelajaran. Bandung: Yrama Widya.

Nana Sudjana, dan Ahmad Rifa'i. 2009. Media Pengajaran. Bandung: Sinar Baru Algesindo

Sugiyono. 2010. Metode Penelitian Pendidikan. Bandung: Alfabeta.

Widoyoko, Eko Putro. 2009. Evaluasi Program Pembelajaran. Yogyakarta: Pustaka Pelajar 